\title{
Combining scenario workshops with modeling to assess future irrigation water demands
}

\author{
Jean-Daniel Rinaudo ${ }^{1}$, Laure Maton ${ }^{1}$, Isabelle Terrason ${ }^{2}$, Sébastien Chazot ${ }^{2}$, Audrey \\ Richard-Ferroudji ${ }^{3}$ and Yvan Caballero ${ }^{1}$
}

(1) BRGM, 1034 rue de Pinville, 34000 Montpellier, France.

$\mathrm{Ph}$ : + 33467157990 . Fax : +33467645851

(2) BRL Ingénierie, Nimes, France.

(3) Cemagref, 361 rue JF Breton, 34033 Montpellier cedex, France.

$\left.{ }^{*}\right)$ Corresponding author; Email: jd.rinaudo@brgm.fr

\begin{abstract}
We discuss methodological issues related to the development of long term future agricultural water demand scenarios. We present the results of original research which combines the use of scenario workshops with quantitative crop water requirement modeling approaches. Using a southern France case study, we describe four scenarios, debated with farmers and stakeholders during workshops and evaluated in terms of total water demand. Results suggest that socioeconomic evolution could lead to a $40 \%$ increase of irrigation water demand. From a methodological perspective, the research highlights the mutual benefits for both policy makers and scientists of involving stakeholders in the development of scenarios, using both qualitative storylines and quantitative modeling tools.
\end{abstract}

\section{Introduction}

In regions where imbalances exist between water demand and available resources, medium and long-term forecasting is a major preoccupation of the water resources and the hydraulic infrastructure managers. This concern is particularly acute in contexts characterized by rapid demographic or economic change, which may create urgent needs for new infrastructure development. Considering the very long lifetime of hydraulic infrastructure (dams, canals inter-basin transfers), water managers must base their decisions on expected water demands over the medium and long term (30 to 50 years, depending on the facilities involved). This proves to be a rather difficult task in basins where agriculture is the main 
water user, given the high uncertainty attached to future agricultural demands and technological developments.

Numerous models have been developed for estimating agricultural water demand at the scale of the region. The simplest modeling approach consists of interfacing agronomic models with geographic information systems (Hartkamp et al., 1999). Scenarios obtained from exogenous macro-economic models can be incorporated into these tools to estimate the long-term development of demand (Weatherhead and Knox, 2000). More complex approaches have also been developed, involving the combination of agronomic models with behavioral models designed to represent farmers' technical and economic choices (Maton et al., 2005; Poussin et al., 2008). Lastly, bio-economic farm models, which use mathematical programming tools, have been widely used to simulate the development of water demand in response to changes in farm policy or water pricing. (Varela-Ortega et al., 1998; Bartolini et al., 2007).

These models are not usually designed to simulate the effects of drastic disruptive economic structural changes (breakdowns) on irrigation-water demand. They assume, rather, that the essential structure of the production system remains stable (structure of production and distribution systems, constraints, price elasticity). However, in a situation of rising uncertainty - simultaneously economic, social, and climatic - decision-makers can no longer make longterm water-management plans without taking into account the possibility of such breakdowns, which can have major impacts (either positive or negative) on water demand, particularly for irrigation farming. In this paper, we illustrate how foresight (or futures studies) can offer a complementary framework to the use of models for assessing the need for irrigation infrastructure development.

Using qualitative approaches, foresight allows accounting for uncertainty through the creation of highly diverse scenarios concerning the development of the economic environment, agricultural production, the very structure of the production systems, and the resulting demand for water. Foresight can help decision-makers explore uncertainty associated to future developments and assess the consequences of the various strategic choices they could make. The approach consists of projecting them into a limited number of scenarios, each of which describes a possible future world. In contrast with predictive approaches, which seek to identify the most probable future outcome or path, the aim here is "to illuminate the choices of the present in the light of possible futures" (Godet and Roubelat, 1996). The expected result is both substantive and procedural: the approach not only enables the parties involved to make a decision that takes uncertainty into account, but also to construct and share in a common representation of the uncertainties and temporal dynamics of the resource-use system that they will have to manage. In turn, this learning experience enables 
a better collective assessment of the infrastructure development options, and more generally in the water-management policy area.

We are particularly interested in foresight methods that employ scenarios as tools for exploring the future. These methods, often referred to as "scenario planning", are not a recent innovation: they were developed in the 1950s in response to the cold war (Kahn and Wiener, 1967), and have been widely used in the corporate world since the 1980s (Millett, 1988). Scenarios and scenario analyses have subsequently become popular approaches for use by planners in the area of sustainable development, with applications to multi-sector economic policy (Rotmans et al., 2000), nature conservation and ecological services (Peterson et al., 2003; Carpenter et al., 2007), greenhouse gas emission scenarios (Nakicenovic and Swart, 2000) environmental impact assessment (Duinker and Greig, 2007), the environmental impacts of agriculture (Poux, 2006; Reed et al., 2009), desertification control (Patel et al., 2007), and urban development and planning (Street, 1997).

However, the application of these methods in the water sector remains limited. In this area the scientific literature mainly reflects the results of foresight approaches deployed at the continental scale (Lake and Bond, 2007), pan-European scale (Kämäri et al., 2008) or the global scale (van der Helm, 2003). Examples include the development of World Water Vision (Gallopin and Rijsberman, 2000) and the results obtained from models such as WaterGAP (Alcamo et al., 2007) and WaterSim (de Fraiture and Wichelns, 2010). Other applications address the urban uses of water (Phelps et al., 2001; Lienert et al., 2006). However, scenario planning at the watershed (or aquifer) scale remains little used, while being the scale at which management are most often considered. The rare examples at this scale are found in the context of research projects (Hatzilacou et al., 2007) or are applied to a particular component of water demand (Westcott, 2004).

The limited penetration of foresight methods into the water sector reflects the existence of unresolved methodological problems. In this article we discuss two of them:

- The first concerns the linking of scenario storylines - by nature qualitative - to quantitative hydrologic and economic modeling tools, on which water managers rely to take decisions. This integration is often carried out in a semi-quantitative manner (Kok and van Delden, 2007), which necessarily involves a relative subjectivity when it comes to quantifying the assumptions made in narrative storylines (Shakley and Deanwood, 2003). Alcamo proposes an interesting Story-And-Simulation approach, in which qualitative and quantitative scenarios are linked in an iterative procedure (Alcamo, 2008). 
- The second problem concerns the participatory aspect that must necessarily be a feature of an exploratory future-study approach. In an environment where predictive approaches are mainly based on modeling tools and the skills of experts, are decision-makers ready to acknowledge the value of contributions from users? Furthermore, are the users capable of freeing themselves from the constraints of the present and escaping the ultra-local scale, to project themselves into the long-term and the scale of the region?

We address these two questions by describing a case study conducted in the Roussillon plain, located in the Eastern Pyrenees County, in the south of France. This is a region where the future of farming, and consequently future water demands are highly uncertain. We illustrate the benefits of the scenario method for analyzing uncertainty surrounding future irrigation-water demands. We describe the participatory foresight approach to exploring the prospects for agriculture and future water demands.

\section{Using scenarios for assessing future water demands}

Estimating future irrigation water demand in a river basin requires assumptions concerning the type of crops and corresponding areas that will be cultivated at the time horizon considered. This in turn depends on many socio-economic and regulatory factors (both internal and external to the basin), that are difficult to predict. Assuming that uncertainty related to this evolution is irreducible, the only option left to water managers that need to plan long term investment is to explore the diversity of possible future developments to evaluate the range in which future water demand might be included. The use of simulation models is one way of exploring future evolution, for instance through Monte Carlo simulation approaches, with the limitations already mentioned in the introduction (see Graveline et al, 2012 for an illustration). We consider an alternative approach of using qualitative but comprehensive scenarios for apprehending uncertainty associated with water demands.

The objectives of forming these scenarios include helping decision-makers be aware of the diversity of possible futures by highlighting the sources of uncertainty over which they have no control (exploratory scenario exercise). But after this phase, in which the uncertainty is discovered, scenarios are used to learn how to manage it, ultimately leading to the development of a strategic action plan. Using scenarios can prepare the actors to confront potentially unfavorable situations, e.g., under- or over-estimation of future water demands, which might either destabilize the system technically or financially, or create opportunities. The scenarios then can play a role in reaching a decision, enabling the actors to re-assess their strategic choices in the context of uncertainty (van Notten et al., 2003) 


\section{Case study and methodology}

\subsection{Case study area}

Our study area is the $700 \mathrm{~km}^{2}$ Roussillon plain in the south of France. With an average precipitation of $570 \mathrm{~mm}$, this region has one of the driest climates in France. The presence of relatively abundant surface water and groundwater has enabled the development of irrigation farming (about 15,000 ha irrigated), which produces mainly vegetables (tomatoes, cucumbers, potatoes, and artichokes) and fruits (peaches, nectarines, and apricots). About 11,000 ha are irrigated by open gravity channels which draw their water from three rivers, two of which are regulated by dams. The remainder of the irrigated area relies on pressure irrigation systems of an estimated 4,500 individual boreholes. The rivers' water regime is typically Mediterranean, with very low water levels in summer.

The doubling of the population between 1954 and 2007 and the development of tourism along the coast have created a substantial increase in drinking-water requirements. These needs have been met by increasing withdrawals of groundwater, leading to a lowering of the water tables and restrictions on the use of boreholes, especially for agriculture. Implementation of the European Water Framework Directive has led to increases in the flows of rivers reserved for environmental-protection purposes, to the detriment of irrigation canals. Several years of drought also have given rise to restrictions on water use.

Long-term predictions of climate change suggest that tensions over water resources are likely to become more severe. According to the work of the Vulcain Project, by 2030 the mean annual temperature is expected to increase by $1.5^{\circ} \mathrm{C}$, and evapotranspiration by $7 \%$. Although no significant change in precipitation is anticipated for 2030, by 2050 it should have fallen by about $15 \%$ in the case study area. The Vulcain Project's hydrologists have also shown that by 2030 river flows are expected to have fallen by about $20 \%$ to $40 \%$, with particularly low levels in summer and autumn (Caballero et al., 2008). These results are consistent with studies conducted at larger scales (Boe et al., 2009).

The availability of water resources could thus become a major constraint on Roussillon's agriculture, especially as vineyard irrigation will increase in a drier climate. Agriculture's economic representatives are therefore calling on public decision-makers to create new water resources, whether by inter-basin transfers (transfers between local rivers or extension of the Rhone river water-supply system) or by establishing new storage capacity.

In parallel with this hydro-climatic context, the development of the agricultural base itself appears relatively uncertain. Since the areas irrigated, the number of operations, and the value of their production have fallen regularly for several decades $(33 \%$ of farms vanished 
between 2000 and 2007, representing at least $10 \%$ of the agricultural area ${ }^{1}$ ), we may reasonably wonder whether the water demand for irrigation is indeed going to rise. It is in this context that we explore the future of agriculture and the demand for irrigation water, by applying the principles of the scenario method described in the preceding section.

\subsection{Methodology}

The foresight methodology includes four steps. The first is identifying the driving forces of change and the sources of uncertainty concerning the development of irrigation farming by 2030 , by drawing on a group of experts and actors in the agricultural sector. The second is preparing four contrasting scenarios for the development of agriculture, which are then opened for discussion (Step 3) during workshops organized separately with experts and farmers. The fourth step is that of developing a model for quantifying the irrigation-water demands associated with the scenarios, as reviewed and corrected by the actors during the workshops. Workshops were organized in 2009 and the rest of the study completed in 2010.

\subsubsection{Identification of driving forces and uncertainties}

The driving forces and uncertainties were identified by eleven experts from Roussillon's agricultural sector, during a preliminary half-day foresight workshop. The expert group included representatives from the farmers' associations, market operators, the administration, and a few scientists. Experts were identified based on a stakeholder analysis conducted as part of a previous project (Aunay et al., 2007; Montginoul and Rinaudo, 2010). During this workshop we asked participants to identify the main factors that had determined the development of agriculture over the last 20 years, considering both factors external (e.g., the entry of Spain into the Common Market in 1981) and internal factors (e.g. development of water resources, urbanization, and the abandonment of farmland). Participants were then invited to discuss the factors most likely to affect the future development of agriculture by 2030 and to list the main sources of uncertainty involved. In parallel with this workshop, discussions were also held with about twenty farmers from the study $\operatorname{area}^{2}$, to complement

\footnotetext{
${ }^{1}$ Source : AGRESTE (French Agricultural Statistics), Recensement Général Agricole for 2000 (Farm Census 2000) and Enquête Structures for 2007 (Farm survey, 2007).

${ }^{2}$ Farmers were recruited with the help of two local institutions, the Chamber of Agriculture and an Association for the development of Organic Farming (CIVAM Bio 66). Selection criteria included the type of production (vine, fruits and/or vegetable), the geographic location, type of water resources used (canal irrigation or groundwater), farm size and the age of farmers. Overall, farmers who were finally recruited were of two different types. A first type consisted of farmers who define themselves as true entrepreneurs, with a real capacity to adapt their technical and economic choices to a changing environment. A second type consisted of farmers already engaged in the search of alternative farm models (e.g. organic farming, producing non regional crops) claiming greater social recognition of agriculture for the many roles it plays beyond food production (e.g. environmental externalities, territorial development, etc.). The team failed in recruiting many other farmers who did not perceive
} 
and enrich the experts' regional outlook with the individual plans for the future that the farmers might have at the level of their own operations.

\subsubsection{Development of contrasting scenarios}

The scenarios were focused on agriculture and its water requirements in 2030 , and only briefly describe the chain of events leading from the 2007 reference situation to that year. Each of the four scenarios was framed in a different external context which was considered to be imposed to the territory itself and not debatable by the stakeholders. Participants were asked only to discuss choices related to factors under local control. Whereas the external assumptions of the four scenarios were drawn from those developed by the La Bussière Group at the national level (Poux, 2006), the narrative description of future agriculture at the local level was based on the views presented by farmers and on imagined components introduced by the authors. The scenarios were clearly designed - and presented as such to stakeholders - as a source of inspiration for the process, not as scientifically sound projections.

\subsubsection{Scenario workshops}

Although the scenario-workshop method usually involves the mixing of policy makers, business representatives, experts, and citizens (Street, 1997; Andersen and Jaeger, 1999; Lienert et al., 2006; Hatzilacou et al., 2007), we decided to set up separate groups for different groups. We also opted for smaller groups (five to eleven persons) in contrast to the scenario groups described in the literature, where each workshop includes between 25 and 40 persons (Andersen and Jaeger, 1999; Hatzilacou et al., 2007; Patel et al., 2007). The existing expert group (11 participants) was therefore supplemented by three groups of farmers. This methodological choice was adopted to overcome the mistrust that characterizes relationships between the farmers and public-sector experts; the creation of homogeneous groups was perceived as facilitating the emergence of mutual trust. In each group of farmers, the three main production activities (wine-growing, fruit, and vegetables) of the traditional sector and of organic farming were represented, as well as the area's geographic diversity. One of the groups consisted mainly of young farmers (under 40 years old) who are likely to have a different view of the outlook for 2030, a time when they will probably still be actively involved. We met separately with each invited farmer before the workshop was convened to present the project's objective and to assess their motivation to participate. They then received by mail a narrative outline of the scenarios (two pages of text per scenario). 
Discussions of the scenarios took place during workshops held over a half-day period in the evening (6 to $11 \mathrm{PM}$ ), and including a meal for the farmers. The workshops were organized as follows. After a brief presentation of the workshop's objectives, a discussion leader presents the first scenario, using a poster as support. The participants are invited to comment individually during a round-table session before discussing any confronting points of view. During this discussion the leader refocuses the debate on the implications of the scenario for water management.

This sequence is then repeated for each scenario. The participants are invited to prepare individual rankings of the four scenarios according to their probability and desirability. Comparison of these pictures of the probable and desirable futures gives rise to a final group discussion. The discussions are recorded to enable subsequent detailed study of the observations. In the next few days after the workshop, telephone interviews are conducted to obtain the participants' opinions concerning the working method and the content of the discussions. A four-page workshop summary report is sent to the participants.

Since workshops were organized in a research context, the objective was not to reach a consensus or to prepare concrete decisions. Instead, the aim was to encourage the expression of various pictures of the future, and to facilitate the mutual discovery of differing points of view concerning future evolution of agriculture and associated irrigation water demands.

\subsubsection{Quantification of scenarios}

The two principal scenarios (the probable and the desirable) which emerge from the workshops are expressed as quantified assumptions, in terms of cultivated areas, irrigated areas, cropping patterns, and irrigation practices.

A model designed to quantify the irrigation water requirements is then developed for each of the eleven watersheds in the study area. For each catchment area $j$, the model calculates the water withdrawal $W W_{j}$ carried out by the farmers, taking into account (1) the climate in the watershed $j$ (which determines the unit crop water requirement $C W R_{i, j}$ for each crop $i$, (2) the areas farmed $S_{i, j}$ for each crop in the watershed $j$, and (3) the irrigation technologies, which are characterized by an efficiency coefficient $E_{j}$.

The model is applied to each of the eleven main sub-catchment areas for which the project team has determined a mean technical efficiency $E_{j}$ for the systems irrigated, the climate, and the areas under cultivation. The model is calibrated by comparing the results of the simulations with the observed data, and then used to perform simulations. The crops water requirements are calculated as follows, in accordance with FAO methodology (Allen et al., 1998): 


$$
C W R_{(i, j)}=\sum_{d=1}^{t}\left(\max \left[0 ;\left(K c_{i, d} \cdot E T_{d, j}-P_{d, j}\right)-R A W_{d-1, j}\right]\right)
$$

Where:

$\mathrm{CWR}_{\mathrm{i}, \mathrm{j}}$ is the crop water requirement of crop $i$ in climatic catchment $j$;

$\mathrm{Kc}_{\mathrm{i}, \mathrm{d}}$ is the crop coefficient of crop $i$ for decade $d$ and climatic catchment $j$;

ET ${ }_{d, j}$ is the evapotranspiration for decade $d$ in climatic catchment $j$;

$\mathrm{P}_{\mathrm{d}, \mathrm{j}}$ is the total precipitation during decade $d$ in climatic catchment $j$;

$\operatorname{RAW}_{\mathrm{d}-1, \mathrm{j}}$ is soil Readily Available Water during decade $d-1$ in catchment $j$.

The water requirements of the crops are calculated at a ten day time step for 13 climatic zones, using values of $\mathrm{Kc}$ appropriate to the terrain ${ }^{3}$. The total demand for irrigation water is calculated for the two scenarios, for each of the 35 climate years from 1971 to 2005 . We then look at the statistical distribution of the results to estimate the value which only exceeded 1 year out of 5 ( 5 years return high water requirements).

\section{Results of the scenario workshops}

\subsection{Identification of the main sources of uncertainty}

During the first foresight workshop the experts identified the main sources of external and internal uncertainty in the region that might have an impact on future water demands. The nine main factors listed in Table 1 provide a good illustration of the wide range of driving forces that may need to be considered when attempting to assess future demands for irrigation water in a region subject to many sources of transformation. The workshop contributed to the construction of a common understanding by participants of the role of these external and internal factors. For the research team, the workshop identified the internal driving forces, as some of them had not been clearly identified through previous field work (factors 6 and 8 of table 1 for instance).

\footnotetext{
${ }^{3}$ In the method selected (crop coefficient approach, the crop evapotranspiration (ETc) is calculated by multiplying the reference crop evapotranspiration (ETo, climatic data) by a crop coefficient, Kc. This Kc coefficient represents an integration of the effects of four primary crop characteristics that determine crop evapo-transpiration: (i) crop height; (ii) albedo (reflectance) of the crop-soil surface; (iii) canopy resistance and (iv) evaporation from exposed soil (Allen et al, 1998). Kc values for the case study have been established by agronomists of BRL, an irrigation company operating in the area.
} 


\begin{tabular}{|c|c|c|c|}
\hline & Factors of change & $\begin{array}{l}\text { Impact on } \\
\text { agriculture }\end{array}$ & $\begin{array}{l}\text { Impact on } \\
\text { irrigation }\end{array}$ \\
\hline & \multicolumn{3}{|l|}{ External factors } \\
\hline 1 & $\begin{array}{l}\text { Reduction in subsidies from the Common Agricultural } \\
\text { Policy }\end{array}$ & decline & - \\
\hline 2 & $\begin{array}{l}\text { Strengthening of environmental regulation: higher } \\
\text { environmental water allocation, increased limitations on } \\
\text { irrigation water use }\end{array}$ & decline & - \\
\hline 3 & $\begin{array}{l}\text { Increases in the cost of energy and of international long- } \\
\text { distance transport, decreased competition from far-distant } \\
\text { countries, enhanced competitiveness of local agriculture }\end{array}$ & revival & + \\
\hline 4 & $\begin{array}{l}\text { Reform of French regulation: irrigation of vineyards } \\
\text { authorized }\end{array}$ & revival & + \\
\hline \multirow[t]{2}{*}{5} & $\begin{array}{l}\text { Urbanization, urban sprawl and loss of farmland, partly } \\
\text { due to the growing influence of Barcelona (commuting } \\
\text { population) }\end{array}$ & decline & \\
\hline & Internal factors & & \\
\hline 6 & $\begin{array}{l}\text { Development of Saint Charles International fruit \& } \\
\text { vegetable market business plateform (rail-road transport) }\end{array}$ & revival & + \\
\hline 7 & $\begin{array}{l}\text { Dismantling of irrigation associations, breakdown of gravity } \\
\text { irrigation canals (partly due to urban sprawl), resulting in } \\
\text { increased individual groundwater use }\end{array}$ & decline & - \\
\hline 8 & $\begin{array}{l}\text { Local policy encouraging the recruitment of young farmers } \\
\text { to replace very high number of retirees expected in the } \\
\text { coming decade }\end{array}$ & decline & - \\
\hline 9 & $\begin{array}{l}\text { Local agricultural policy encouraging the production of } \\
\text { environmental services by agriculture (protection of } \\
\text { landscape, biodiversity, groundwater recharge through } \\
\text { irrigation). }\end{array}$ & revival & $=$ or + \\
\hline
\end{tabular}

Table 1: Principal factors of change identified by the actors in the first workshop.

\subsection{Scenarios discussed}

The sources of uncertainty identified by the actors, together with several other factors described in the literature ${ }^{4}$, were employed to define four contrasting scenarios for the development of agriculture in Roussillon. These scenarios are set out below and summarized in table 2.

\footnotetext{
${ }^{4}$ Literature concerning possible future evolution of: Common Agricultural Policy; fruits, vegetable and vine markets; agricultural demography; local urban development; agronomic innovation.
} 


\begin{tabular}{|c|c|c|c|c|c|}
\hline Driving forces & Current situation & S1 - Ultra-competitive agriculture & S2 - Two tiers agriculture & S3-Regional development & S4 - High environmental performance \\
\hline $\begin{array}{l}\text { Agricultural } \\
\text { market }\end{array}$ & $\begin{array}{l}\text { Liberalization } \\
\text { trend. Increasing } \\
\text { international } \\
\text { competition \& } \\
\text { import of } \\
\text { agricultural } \\
\text { products on EU } \\
\text { market. Petrol } \\
\text { price }: 40 \text { to } 140 \\
\$ / \text { barrel }\end{array}$ & $\begin{array}{l}\text { Strong competition from non-European } \\
\text { countries (Latina America) due to } \\
\text { extreme liberalization of trade and low } \\
\text { petrol price ( } 75 \$ / \text { barrel). } \\
\text { Very low agricultural prices determined } \\
\text { by world market } \\
\text { Consumers mostly purchase cheap } \\
\text { standardized food product in hard } \\
\text { discount supermarkets (origin of } \\
\text { products does not matter) }\end{array}$ & $\begin{array}{l}\text { Moderate international competition } \\
\text { due to liberalization and } \\
\text { intermediate petrol price (125\$) } \\
\text { Market segmentation: cheap \& } \\
\text { standard food products (S1) for } \\
\text { supplying industrial / discount } \\
\text { supermarkets. } \\
\text { Local higher quality products sold on } \\
\text { regional market (direct sales, } \\
\text { specialized retail shops) }\end{array}$ & $\begin{array}{l}\text { Trade liberalization limited by strong EU } \\
\text { norms (quality of EU products slightly } \\
\text { higher than on international markets). } \\
\text { Emergence of high quality / high added } \\
\text { value food products for niche markets. } \\
\text { Export boosted by regional marketing } \\
\text { policy } \\
\text { For cheap products, international } \\
\text { competition reduced due to high petrol } \\
\text { price ( } 150 \$ \text { /barrel) \&transportation cost }\end{array}$ & $\begin{array}{l}\text { Access to the EU market is restricted by } \\
\text { health regulation (zero pesticide } \\
\text { products). } \\
\text { EU food products are sold at price that } \\
\text { exceeds those on the world market. } \\
\text { International competition limited by } \\
\text { high petrol price }(150 \$ / \text { barrel). EU } \\
\text { reduces its agricultural exports. }\end{array}$ \\
\hline $\begin{array}{l}\text { European } \\
\text { Common } \\
\text { Agriculture } \\
\text { Policy (CAP) }\end{array}$ & $\begin{array}{l}\text { Total CAP budget } \\
=€ 12 \text { billion }\end{array}$ & $\begin{array}{l}\text { Current policy dismantled (end of } 1 \text { rst } \\
\& 2^{\text {nd }} \text { pillar of the CAP). CAP limited to } \\
\text { investment subsidies granted to large } \\
\text { farms. Total CAP budget }=€ 3 \text { billion } \\
(€ 10000 / \text { labor unit) }\end{array}$ & $\begin{array}{l}\text { Strengthening of CAP, two tiers } \\
\text { approach: for large farms, } \\
\text { investment subsidies; for small } \\
\text { farms, subsidies for environmental } \\
\text { services Total CAP budget }=€ 7 \\
\text { billion ( } € 25000 \text { / labor unit) }\end{array}$ & $\begin{array}{l}\text { Transferred to Regions which develop their } \\
\text { own policy to maximize their competitive } \\
\text { advantage. Total CAP budget = } € 6 \text { billion } \\
\text { (€11 } 600 / \text { labor unit) }\end{array}$ & $\begin{array}{l}\text { Subsidies coupled to production again. } \\
\text { Total CAP budget }=€ 12 \text { billion } \\
(€ 12000 \text { / labor unit) }\end{array}$ \\
\hline $\begin{array}{l}\text { Social } \\
\text { demand for } \\
\text { agricultural } \\
\text { products and } \\
\text { services }\end{array}$ & $\begin{array}{l}\text { Food purchase } \\
\text { represents } 15 \% \text { of } \\
\text { households' } \\
\text { budget. 13\% } \\
\text { households } \\
\text { purchase food in } \\
\text { hard discount } \\
\text { supermarkets. } \\
\end{array}$ & $\begin{array}{l}\text { Cheap food product (food purchase = } \\
10 \% \text { of households' budget). } 60 \% \text { of } \\
\text { households purchase food in hard } \\
\text { discount supermarkets. Environment is } \\
\text { not a key preoccupation. Agriculture, a } \\
\text { business as any other. }\end{array}$ & $\begin{array}{l}\text { Cheap food product \& environmental } \\
\text { services. Two forms of agriculture } \\
\text { coexist. Households willing to spend } \\
15 \% \text { of their budget for food } \\
\text { purchase. }\end{array}$ & $\begin{array}{l}\text { High quality agriculture contributes to the } \\
\text { development of the regional repute, } \\
\text { together with tourism, natural assets } \\
\text { Agriculture contributes to employment and } \\
\text { the chain of value creation } \\
\text { Households willing to spend } 17 \% \text { of their } \\
\text { budget for food purchase. }\end{array}$ & $\begin{array}{l}\text { Social demand for food safety } \\
\text { \&environmental quality. Agriculture } \\
\text { considered as essential for the } \\
\text { mainstay of economic activity in rural } \\
\text { areas. The agricultural sector is an } \\
\text { attractive sector for skilled labor force } \\
\text { Food purchase }=22 \% \text { of households' } \\
\text { budget. }\end{array}$ \\
\hline $\begin{array}{l}\text { Economic } \\
\text { structure of } \\
\text { the } \\
\text { agricultural } \\
\text { sector }\end{array}$ & $\begin{array}{l}660000 \text { farms, } 1 \\
\text { million labor units } \\
\text { in France } \\
4000 \text { farms in the } \\
\text { case study area }\end{array}$ & $\begin{array}{l}\text { Large commercial farm with high } \\
\text { technology / high capital needs. } \\
\text { Intensive use of seasonal foreign cheap } \\
\text { labor. Current family farms, unable to } \\
\text { compete, disappear. } \\
120000 \text { farms in France, } 300000 \text { labor } \\
\text { units. } 750 \text { farms in the case study area }\end{array}$ & $\begin{array}{l}\text { Large commercial farms ( } 33000 \\
\text { farms, } 94000 \text { labor units) coexist } \\
\text { with small/medium family farms } \\
\text { (183000 farms, } 260000 \text { labor units) } \\
1500 \text { farms in case study area }\end{array}$ & $\begin{array}{l}\text { Strong vertical integration (farms, small } \\
\text { food \& beverage industry, marketing) } \\
\text { through new forms of cooperatives, } \\
\text { supported by a voluntarist regional policy } \\
\text { (technical support, funding of integrated } \\
\text { projects). } 400000 \text { farms in France. } 3000 \\
\text { farms in case study area }\end{array}$ & $\begin{array}{l}\text { Small-medium farms. high technology/ } \\
\text { high labor /moderate capital needs } \\
\text { New forms of cooperatives for } \\
\text { marketing / products transformation } \\
500000 \text { farms in France, } 1 \text { million labor } \\
\text { units. } 4500 \text { farms in case study area }\end{array}$ \\
\hline $\begin{array}{l}\text { Cultivated } \\
\text { and irrigated } \\
\text { area }\end{array}$ & & $\begin{array}{l}\text { Urban sprawl \& decrease of number of } \\
\text { farms -> strong reduction of cultivated } \\
\text { area. Improvement of irrigation } \\
\text { performance (drip irrigation) -> overall } \\
\text { decrease of irrigation demand }\end{array}$ & $\begin{array}{l}\text { Modernization of irrigation practices } \\
\text { (-15\% water use per hectare). } \\
\text { Increase area of irrigated vines. } \\
\text { Overall, stabilization of water } \\
\text { demand }\end{array}$ & $\begin{array}{l}\text { Construction of a regional aqueduct, water } \\
\text { supply unlimited at affordable price. } \\
\text { Increase in irrigated area => water demand } \\
\text { increases. }\end{array}$ & $\begin{array}{l}\text { Improvement of irrigation technologies } \\
\text { offset by increased irrigated area. } \\
\text { Overall, increase in water demand. }\end{array}$ \\
\hline
\end{tabular}

Table 2: Overview of scenarios presented to workshop participants. 


\subsubsection{Scenario 1: Ultra-competitive farming}

In the context of a liberalization of global trading, the Common Agricultural Policy is dismantled by 2030 . This development is partially offset, in France, by the implementation of a national policy of competitive modernization of agricultural businesses (investment grants). Moreover, purchasing power is the main preoccupation of the French, who buy their groceries in hard-discount retail chains. Product standardization increases. In this situation, only the very biggest fruit and vegetable production systems in the Roussillon survive, and these are partly owned by outside investors. In wine-growing, barely a hundred large producers and a few restructured cooperative cellars are operating on an area one quarter of what it was in 2010. The family farm has almost vanished. Growing urbanization of the land intensifies the effects of this economic development. Gravity irrigation systems are progressively dismantled and replaced by boreholes tapping shallow and deep aquifers. Overall, demand for irrigation water declines sharply.

\subsubsection{Scenario 2: Two-tier farming}

In 2030 two kinds of farming coexist in the Roussillon: 150 to 200-ha agricultural enterprises that compete in global markets, producing mainly bulk quantities of cheap fruit and vegetables; and multipurpose 50-ha farms, most of which are strongly subsidized for the production of environmental services, with production contributing to income in only a secondary fashion. The new Common Agricultural and Rural Policy (CARP) provides assistance to both of these farming activities through separate subsidy systems. Agrotourism - whose development is strongly supported by both the Region and the County - has become a major source of outside income for the multipurpose farms. Population growth is divided equally between the hinterland and the plain, and poses no threat to farmland. In mountainous areas, the farms benefit from additional support systems, such as grants for transhumant droves, and local landscape maintenance contracts, operated by the communes. Organic farming is occupying greater areas (20\%), particularly within multipurpose operations which benefit from eco-conditional grants and a buoyant market. As regards water management, now that the multiple uses of irrigation canals have been widely demonstrated (groundwater recharge, urban water supply, storm water evacuation during heavy rain periods), their agricultural applications are being promoted by public grants. Withdrawals of groundwater for farming purposes are being regulated and progressively reduced, while the management of existing dams has been optimized, increasing the quantities available for irrigation. Overall, agricultural water demand remains at 2010 levels.

\subsubsection{A regionalized agricultural development in Europe}


By 2030 the regions have become the places where new farm policies are developed. Using European Community budgets allocated on the basis of criteria that combine total operated area, rural population, level of economic development, and environmental situation, each region applies itself to optimizing its comparative advantages. The Languedoc-Roussillon Region has invested in the development of a diversified agriculture with a very high added value, based on high-range productions aimed at European and world markets. It has created a system of training schemes for farmers, contributed to the establishment of new regional food / beverage industries and distribution chains with good vertical integration, and very actively supports the creation and promotion of new brands and controlled appellations. The "Sud Intense: colours - tastes - lands" brand, created by the Regional Agency for the Promotion of Local Products (founded in 2020), has acquired an international reputation that encourages the export of fresh farm produce (fruit and vegetables) and their transformed products (wine, olive oil, crystallized fruit, etc.). The balance of power between distribution and agriculture has shifted, to the advantage of the producers. After a long period of crisis, areas occupied by vineyards are again increasing, reaching 2010 levels by 2030 . Arboriculture has diversified, with the return of the olive tree (controlled appellations oils), the cherry and selected older varieties of apricot and peach. Moreover the Roussillon population, now highly urbanized, is voicing vigorous social demands concerning protection of the environment, the quality of life, natural resources, and the landscape. These demands are leading to the signing of contracts between farmers and local authorities, under regional umbrella projects. These contracts address "the introduction or continuation of activities contributing to the economic, social, and environmental development of farming". The demand for irrigation water experiences a significant rise, which can be met by larger withdrawals from existing dams, in particular from Villeneuve-de-la-Raho reservoir, which has been under-used for many years. Additional water resources are also developed.

\subsubsection{Scenario 4: High-Performance Environmental Farming}

Environmental expectations govern the demands of European and French society. The use of pesticides is totally banned since 2022. A model of farming certified as "High-Performance Environmental Farming" has been progressively imposed. Inspired by organic farming, but with a somewhat relaxed version of its technical constraints (fertilization, use of drugs in rearing), HPE farming retains the prohibition against pesticide use. The Roussillon has positioned itself as a pioneer in the development of HPE by using its three major assets: a highly-favorable climate (hours of sunshine, and wind) ; experience in organic farming, which has been growing since the 2010-2020 period; and the proximity of the Montpellier agronomic research centers. A European Agricultural Policy along the lines of the 1960s one has been established: it encourages HPE production through production subsidies, finances 
investments for the restructuring of traditional farming on the HPE model and for training and research. It also provides financial support for the transformation of downstream distribution chains (agro-processing industry and product-packaging facilities). The distribution of food products follows a model completely different from the dominant model of the 2010-2020 period. Products are less standardized (more varied grading), and they travel shorter distances, both because of the higher cost of transport and because of the constraints imposed on packaging (requirement for recovery and recycling). In addition, the requirement for dual display of both producer and consumer prices has led to a sharp drop in distributor profit margins. Finally, since the EU imposes higher environmental standards on food products (zero pesticide), the prices establish themselves above world prices of conventional products. Overall, agriculture in the Roussillon experiences unusually dynamic growth in terms of the area farmed, the recruitment of young farmers, new jobs, and added value. As a direct consequence, the consumption of irrigation water rises very steeply.

\subsection{Assessment of the scenarios}

The discussions that took place during the four workshops mainly concerned the future of farming, demand for water being seen as a consequence of socio-economic development. After a discussion of each scenario, the participants were asked to provide individual rankings of the scenarios from more to less probable, and from more to less desirable. Figure 1 summarizes the classifications made by the professional experts (11) and the farmers (15).

Only $8 \%$ of the participants want to see the outcome described in Scenario 1 (ultracompetitive farming), although $33 \%$ of them think it will probably come to pass. This scenario is perceived as an alarmist but realistic portrayal of the situation that could result from a combination of unfavorable changes in the overall economic environment, and a lack of activist projects from the profession itself. A danger of irreversibility is associated with this scenario, since a declining agriculture could lead within a few years to a complete dismantling of land-ownership structures, of irrigation systems, of the farmers' technical expertise, and more generally of the human and social capital (Figure 2). The participants confirm that this scenario would lead to a fall in the demand for irrigation water.

Scenario 2 (two-tier farming) is the outcome judged to be the most probable (by $54 \%$ of participants) while not being perceived as desirable (36\%), in particular because it makes farming more dependent on subsidies than in the 2007 reference situation. However, the participants believe that this scenario represents a transition situation that could last for only a brief time before evolving either in the direction of Scenario 1, or towards Scenario 3 or 4 
(Figure 2). Accordingly, we did not use this scenario to quantify the requirements for water in 2030 in the continuation of the study.

In contrast, Scenarios 3 and 4 were perceived overall as representing goals that were desirable to reach $(72 \%$ and $80 \%$ of participants), especially as they enable farmers to live off their earnings, to create added value and employment, and to contribute to regional economic development. The participants suggested that the assumptions derived from these two scenarios could be combined. However, these scenarios are considered to be less likely to happen than the two others ( $46 \%$ and $38 \%$ judge S3 and S4 to be probable) because they assume a high level of activism on the part of the political and economic actors in the European, national, regional, and local arenas. Both of these scenarios would lead to an increase in the demand for irrigation water.

At the conclusion of the workshops, two scenarios were adopted for the quantification of water requirements: Scenario 1, which assumes an overall decline of farmland, leading to a probable reduction in water demand; and a hybrid scenario combining the main assumptions of scenarios 3 and 4 , which assumes a revival of farming activity and an increase in water demand.

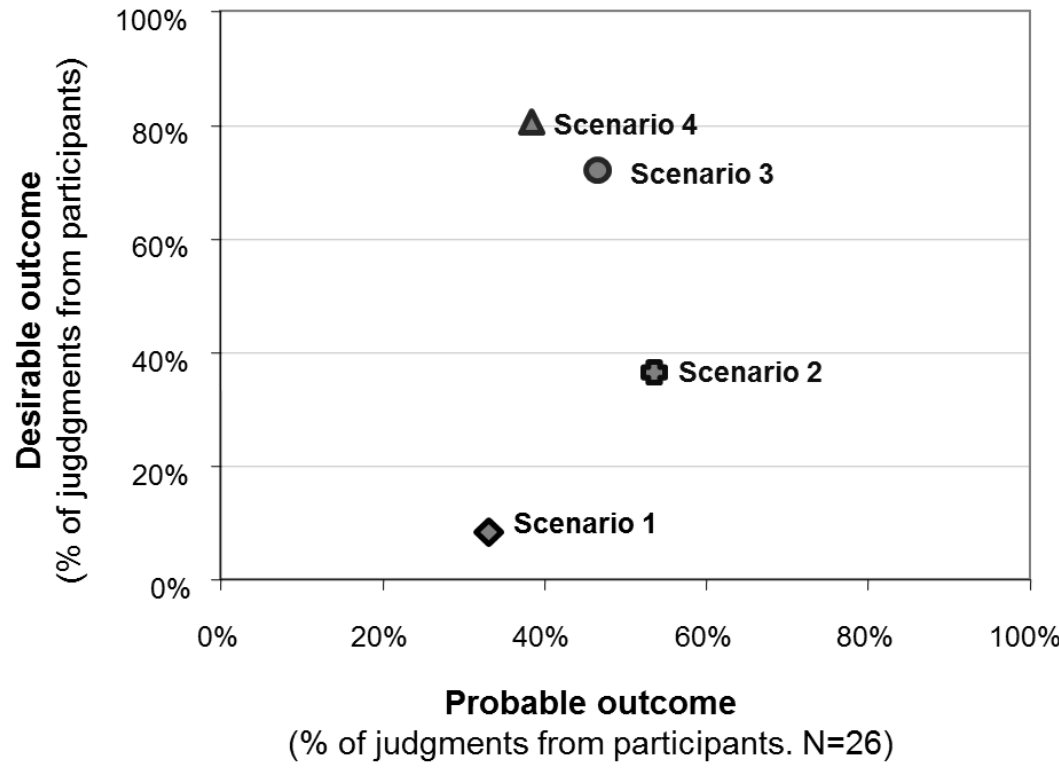

\section{Scenario short description}

S1- Ultra-competitive farming: an alarmist, but realistic outcome given a combination of unfavorable external changes

S2- Two-tier agriculture: coexistence of ultracompetitive farming and subsidized small scale environment oriented farming

S3- Regionalized development agriculture: high added value export oriented agriculture, supported by integrated agricultural regional policy

S4- High-performance environment agriculture: an outcome resulting from the ban of pesticide in Europe the return of a subsidized agriculture and partial protectionism

Figure 1: Workshop participants' perceptions of the desirable and probable natures of the four scenarios discussed 


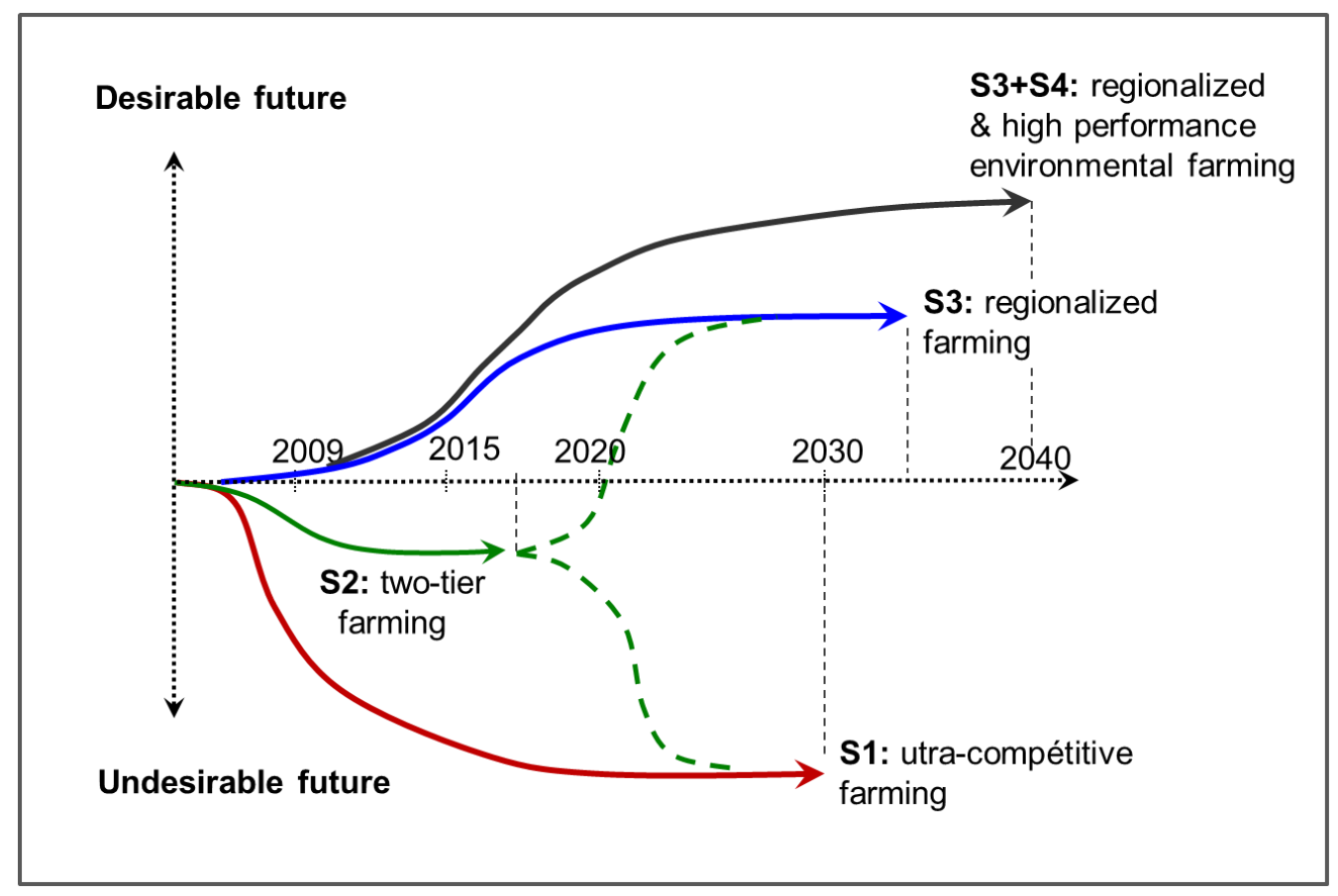

Figure 2: Perceptions of the possible paths associated with the various scenarios

\section{Quantification of irrigation water demand}

\subsection{From narratives to quantified scenarios}

The text describing the scenarios, distributed to workshop participants, contained a table summarizing underlying assumptions (crop areas, irrigated areas, and number of farming operations). These assumptions were submitted to all workshop participants for their review but only experts were able to critically discuss them. The final decision concerning these assumptions was taken by the research team, in light of the views expressed in the workshops. The requirements for irrigation water were estimated on this basis, using the model described above and for a dry year context (Table 3). Changes in irrigated area which are assumed in scenario " $3+4$ " are fully compatible with local land, water and economic constraints. Overall, the new dynamics assumed in scenario $3+4$ would bring agriculture back to its 1990's level in terms of area, but with a higher added value. Cooperatives would not face any problems to transform and commercialize the additional fruit and vegetable production and the increased production would not be significant enough to impact prices on the European market. Also note that the significant increase in irrigated vineyards assumed in the " $3+4$ " scenario does not correspond to newly planted areas but to the conversion of existing vineyards into irrigated vineyards. 


\begin{tabular}{|c|c|c|c|c|c|c|}
\hline & \multicolumn{2}{|c|}{$\begin{array}{l}\text { Reference } \\
\text { situation }\end{array}$} & \multicolumn{2}{|c|}{$\begin{array}{c}\text { S1: } \\
\text { ultracompetitive } \\
\text { farming }\end{array}$} & \multicolumn{2}{|c|}{$\begin{array}{c}\text { S(3+4): Regionalized } \\
\text { development \& high } \\
\text { performance } \\
\text { environmental }\end{array}$} \\
\hline & in ha & $\begin{array}{r}\text { in \% of total } \\
\text { agricultural } \\
\text { area }\end{array}$ & in ha & $\begin{array}{r}\text { variation } \\
\text { in \% of } \\
\text { reference }\end{array}$ & in ha & $\begin{array}{r}\text { variation in \% } \\
\text { of reference }\end{array}$ \\
\hline Total irrigated area & 15384 & $100 \%$ & 17277 & $+12 \%$ & 24580 & $+60 \%$ \\
\hline peach & 8175 & $53 \%$ & 6949 & $-15 \%$ & 9352 & $+14 \%$ \\
\hline apricot & 1330 & $9 \%$ & 1131 & $-15 \%$ & 1596 & $+20 \%$ \\
\hline cherry & 547 & $4 \%$ & 465 & $-15 \%$ & 602 & $+10 \%$ \\
\hline apple & 98 & $1 \%$ & 83 & $-15 \%$ & 196 & $+100 \%$ \\
\hline olive & 105 & $1 \%$ & 95 & $-10 \%$ & 210 & $+100 \%$ \\
\hline vegetables & 3667 & $24 \%$ & 3080 & $-16 \%$ & 4557 & $+24 \%$ \\
\hline vineyards & 534 & $3 \%$ & 4731 & $+786 \%$ & 6800 & $+1173 \%$ \\
\hline grasslands & 913 & $6 \%$ & 730 & $-20 \%$ & 867 & $-5 \%$ \\
\hline cereals & 15 & $0 \%$ & 14 & $-10 \%$ & 400 & $+2567 \%$ \\
\hline $\begin{array}{r}\text { Estimated crop } \\
\text { water requirements } \\
\left(\text { in million } \mathrm{m}^{3}\right) \\
\end{array}$ & $\begin{array}{c}87.3 \\
\text { million } \\
\mathrm{m}^{3}\end{array}$ & -- & $\begin{array}{c}83.4 \\
\text { million } \\
\mathrm{m}^{3} \\
\end{array}$ & $-4.5 \%$ & $\begin{array}{c}124.7 \\
\text { million } \\
\text { m3 } \\
\end{array}$ & $+42.8 \%$ \\
\hline
\end{tabular}

Table 3: Quantification of irrigated areas by crop and irrigation-water requirements (allowing for irrigation efficiency) for two scenarios in dry year context.

\subsection{Simulated impact of scenarios on water demand}

In the first scenario, irrigated crops areas decline by about $15 \%$, but this is offset by an increase in vineyard irrigation, which is considered to be a strong trend. Overall this scenario leads to a decline of about $4 \%$ in water withdrawals in the study area during the irrigation period (April-October). This decline is relatively small in comparison with the opinion expressed by the workshop participants. In Scenario $(3+4)$, there is a vigorous renewal of farming, leading to an increase in the areas under fruit (+37\%) and vegetables $(+24 \%)$. This scenario leads to an increase of about $43 \%$ in withdrawals of water during the irrigation period, part of which is also due to vineyard irrigation.

A more detailed examination of the time distribution of water demand in Scenario $(3+4)$ suggests that the stresses are likely to become particularly acute during the summer. Water requirements will increase by about $50 \%$ from June to August, going from 20 to 30 million $\mathrm{m}^{3}$ in June and July, and from 30 to 45 million $\mathrm{m}^{3}$ in August (Figure 3). 


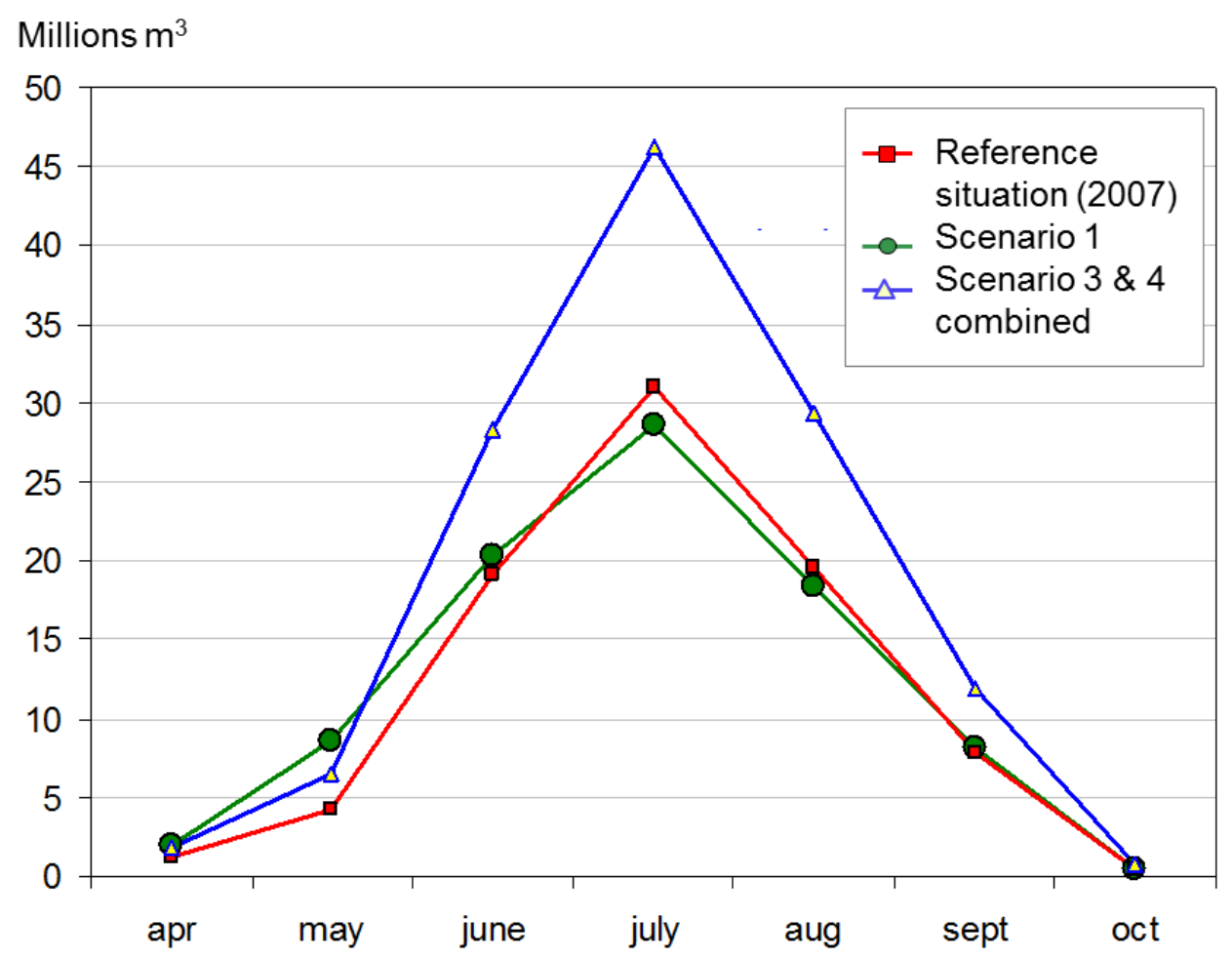

Figure 3: Estimated monthly water demand in the 2007 reference situation and under Scenarios 1 and (3+4).

Similarly, examination of the spatial distribution of future water demand shows that the growth in requirements associated with Scenarios 1 and $(3+4)$ will mainly occur in a few subbasins. In both scenarios the development of vineyard irrigation will have particularly severe consequences in the two northern sub-basins (Agly and Verdouble) where due to the development of vine irrigation, water demand will increase by of $248 \%$ and $548 \%$ (Scenario 1) and by $274 \%$ and $650 \%$ in Scenario (3+4) (Figure 4). These new demands are likely to be partly satisfied by a reservoir located on the Agly river which is not yet fully used. New water demands associated with increased orchard area in the central Têt valley will be more difficult to meet, given the level of tension that already exist in that basin. And new demands in the Roussillon plain (west of the area) will probably lead to increased groundwater pumping in the shallow aquifer, with possible over-exploitation risks. 


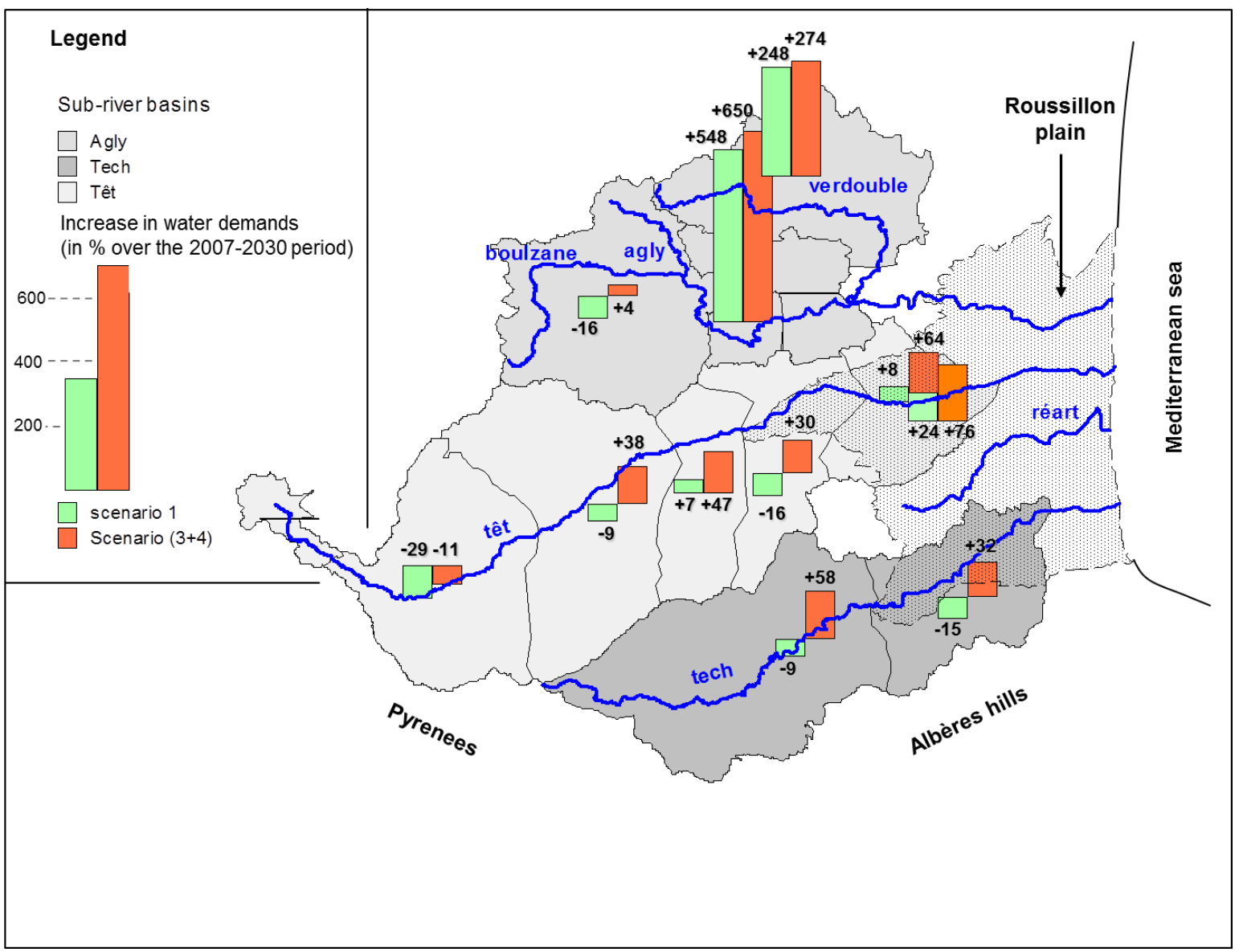

Figure 4: Variation of water demands for irrigation in each of the 11 sub-basins for Scenario 1 and Scenario (3+4), in \% over the 2007-2030 period.

\section{Discussion}

\subsection{Stakeholders' evaluation of research}

The research protocol was evaluated by means of telephone debriefing interviews with all workshop participants. The positive feedback received shows that farmers, experts, and institutional representatives alike appreciated the opportunity for debate offered by the scenario workshops, confirming the conclusions of other similar experiments (Hatzilacou et al., 2007; Patel et al., 2007).

All of the participants said they found the discussion time valuable. The workshop offered them a unique opportunity to think about the consequences of long-term changes, something which neither farmers nor institutional experts have time to do, being trapped in their present constraints and short term objectives. Another key motivation for participants was the opportunity offered by the workshop to listen to each other's opinions, in a strategic behaviorfree context. This was emphasized by the institutional experts, who are used to meeting in 
arenas where they have to defend vested interests and entrenched positions dependent on their institutions, with regard to short-term political and economic issues. The enthusiasm of the participants was subsequently confirmed by their participation in two additional series of workshops which were organized six and twelve months later to discuss the impact of climate change on agriculture, water management, and water-allocation mechanisms in a world with ever-scarcer water resources (Rinaudo et al., 2012).

Workshop participants appreciated the neutrality of the research team, which was operating under EU and national funding, independently from any local stakeholder. This was clearly expressed at the end of the workshops as they rejected our proposal to revise the scenario narratives based on workshop output. By doing so, scenario narratives would have become an official reference with a possible risk of interference in the policy making process. To remain neutral, researchers were invited to keep away from any kind of normative approach. The situation would have been much different if workshops had been organized under the patronage of a local institution (Chamber of Agriculture or Water Commission for instance).

Concerning the use of pre-established scenarios, several participants (both experts and farmers) mentioned they found it difficult, at the beginning of the workshop, to grasp how to use scenarios as a basis for discussion. In fact, most of them used the time devoted to discussion of the first scenario to express their feelings on how things were likely to evolve rather than to describe how agriculture would evolve if the assumptions related to external conditions were to turn out as described in Scenario 1. However, the objective of the scenario exercise became clear after discussing the first scenario. Overall, participants found the four scenarios useful as a basis for discussion, recognizing that exploring possible futures would have been difficult without such support. Most of them found the scenarios sufficiently different, although a few farmers criticized the research team for its lack of imagination: they would have expected at least one scenario to include, for instance, assumptions related to a world food crisis. They appreciated receiving scenario descriptions in advance and found that the two-page format was appropriate. A small number of participants admitted that they did not have time to read the documents before the workshop.

\subsection{Difficulty of linking the narrative storylines with models of water demand}

The experts as a group found the process of quantifying the assumptions for each scenario very difficult, while the farmers were unwilling to discuss these assumptions. This constituted a setback for our working method, which consisted of linking the scenario workshops to models of water demand. The discussions aroused by the storylines mainly addressed the causal links between the factors determining the dynamics of the system studied, and the state of that system. Quantification was then perceived by the participants as a highly 
reductive exercise, in opposition to the intellectual freedom associated with the process of exploring possible futures. Ultimately, then, it came down to the researchers leading the foresight exercise to quantify the assumptions, in light of the qualitative viewpoints expressed in the workshops.

To make it easier for workshop participants to grasp the quantified assumptions, it would have been necessary to formulate these assumptions at a more local scale: the eleven subcatchment areas depicted in figure 4 above. This is in fact the scale at which the farmers and experts are able to formulate hypotheses of the growth or shrinkage of the areas under cultivation, by incorporating into their analysis their knowledge of the human, pedologic, climatic, and other constraints. It is at this same scale that it would have been necessary to refine the assumptions concerning the improvement of irrigation efficiency, examining scenarios for modernizing the infrastructure of irrigation area by area. To perform this quantification would have required the establishment of four or five geographic working groups involving local experts.

\subsection{The added value of scenario workshops}

By combining modeling with a participatory approach, the scenarios developed in this research have become a tool that can improve dialogue between stakeholders and scientists. For engineers and water resource modelers, what really matters is the set of quantitative assumptions associated to each scenario (the term scenario is indeed used as a synonym for "forcing data set"). For stakeholders, the key components of the scenarios are assumptions related to driving forces which are depicted in a consistent vision of future development of irrigated agriculture. Once the quantitative and qualitative facets of the scenarios have been connected, the two communities can really dialogue on the consequences associated to different future developments.

More generally, the workshops enabled the actors to construct a shared knowledge base concerning the uncertainties to which agriculture is exposed. This knowledge base is a prerequisite for a collective discussion of the solutions that might be applied to deal with possible water-resource availability problems.

The workshops' contribution extends far beyond its initial scope. By exploring scenarios that represent both feared and desired developments, the workshops have drawn attention to priorities for actions in the field of agricultural development as well as in water management. As regards water management, the workshops have highlighted a certain consensus around the following ideas: (1) priority must be assigned to maintenance of the canal system and of the associations that manage it; (2) more efficient management of the existing hydraulic infrastructure of dams and canals should go some way towards meeting an increase in 
demand; (3) the creation of new water resources (small reservoirs) might be necessary in certain areas, but the development of agriculture will not require the construction of a major new dam or the construction of an inter-basin pipeline. This finding illustrates the manner in which scenario workshops can contribute to starting a debate on the future aspects of management at watershed scale.

\subsection{Methodological conclusions and recommendations}

Our experience confirms the pertinence of some of the methodological choices made to engage stakeholders in a debate that does not relate to immediate sources of concern: (1) farmers and experts can contribute actively to the exploration of alternative futures even if the participation process does not lead to a decision; (2) lay participants (farmers) are able to explore futures 30 years ahead even though their time horizon is usually much shorter; (3) the use of a limited number of predefined scenarios facilitates the stakeholders' exploration of possible futures; (4) the establishment of separate groups for farmers and institutional representatives seems to be a necessary condition for enabling free expression and debate involving diverging opinions (5) the recruitment of participants should be guided by the participants' motivation and willingness to invest time and energy in the participation process rather than by considerations of representativeness; (6) the choice of a deliberative format aiming at the comparison of opposing visions enables fruitful discussions even if it does not lead to a consensus.

In conclusion, our experience suggests that scenario workshops can usefully supplement modeling methods in predicting the long-term development of irrigation-water demand. Moreover, these studies enable the involvement of the actors in identifying the issues associated with the growth of irrigation, in accordance with Article 14 of the European Water Framework Directive.

\section{Acknowledgements}

Our research was financially supported by the French Research Agency (ANR) as part of the VULCAIN ANR project. We also received financial support from the Ministry of Ecology and Sustainable Development under the AQUIMED project (Circle-Med Era Net initiative). We acknowledge the very useful comments from two anonymous referees and from the editor Dennis Wichelns. The usual disclaimer applies.

\section{References}

Alcamo, J., 2008. The SAS approach: Combining qualitative and quantitative knowledge in environmental scenarios. In: Alcamo, J. (Ed.), Environmental Futures: The Practice of Environmental Scenario Analysis. Elsevier, Amsterdam, pp. 123-150. 
Alcamo, J., Flörke, M., Märker, M., 2007. Future long-term changes in global water resources driven by socio-economic and climatic changes. Hydrological Sciences Journal 52, 247-275.

Allen, R.G., Pereira, L.S., Raes, D., Smith, M., 1998. Crop evapotranspiration - Guidelines for computing crop water requirements. In: FAO (Ed.), Irrigation and Drainage Paper. FAO, Rome, p. 56.

Andersen, I.-E., Jaeger, B., 1999. Scenario workshops and consensus conferences: towards more democratic decision-making Science and Public Policy 26, 331-340.

Aunay, B., Dorfliger, N., Duvail, C., Grelot, F., LeStrat, P., Montginoul, M., Rinaudo, J.-D., 2007. A multidisciplinary approach for assessing the risk of seawater intrusion in coastal aquifers: the case of the Roussillon Basin (France). In: Chery, L., de_Marsilly, G. (Eds.), Aquifer Systems Management: Darcy's legacy in a world of impending water shortage. Balkema Publisher, The Netherlands.

Bartolini, F., Bazzani, G.M., Gallerani, V., Raggi, M., Viaggi, D., 2007. The impact of water and agriculture policy scenarios on irrigated farming systems in Italy: An analysis based on farm level multi-attribute linear programming models. Agricultural Systems 93, 90-114.

Boe, J., Terray, L., Martin, E., Habets, F., 2009. Projected changes in components of the hydrological cycle in French river basins during the 21st century. Water Resources Research 45.

Caballero, Y., Chaouche, K., Neppel, N., Salas y Melia, D., Martin, E., Terrasson, I., Chazot, S., Citeau, J.-M., Maton, L., Rinaudo, J.-D., Fleury, P., Ladouche, B., Dorfliger, N., Pinault, J.-L., 2008. Vulnerability of Mediterranean hydrosystems to climate changes and human activities: assessing potential impacts of likely future precipitation and temperature modifications for the 2020-2040 and 2040-60 periods over a Mediterranean basin. World Congress of the European Water Resources Association, Montpellier, France.

Carpenter, S.R., Bennett, E.M., G.D, P., 2007. Scenarios for Ecosystem Services: An Overview. Ecology \& Society.

de Fraiture, C., Wichelns, D., 2010. Satisfying future water demands for agriculture. Agricultural Water Management 97, 502-511.

Duinker, P.N., Greig, L.A., 2007. Scenario analysis in environmental impact assessment: Improving explorations of the future. Environmental Impact Assessment Review 27, 206-219.

Gallopin, G.C., Rijsberman, F., 2000. Three global water scenarios. International Journal of Water 1.

Godet, M., Roubelat, F., 1996. Creating the future: the use and misuse of scenarios. Long Range Planning 29, 164-171.

Hartkamp, A.D., White, J.W., Hoogenboom, G., 1999. Interfacing geographic information systems with agronomic modelling: a review. , . Agronomy Journal 91, 761-772.

Hatzilacou, D., Kallis, G., Mexa, A., Coccosis, H., Svoronou, E., 2007. Scenario workshops : a useful for participatory water resources planning ? Water resources research 43, 1 à 12.

Kahn, H., Wiener, A.J., 1967. The year 2000 : a framework for speculation of the next 33 years. . Macmillan, New York. .

Kämäri, J., Alcamo, J., Bärlund, I., Duel, H., Farquharson, F., Flörke, M., Fry, M., HoughtonCarr, H., Kabat, P., Kaljonen, M., Kok, K., Meijer, K.S., Rekolainen, S., Sendzimir, J., Varjopuro, R., Villars, N., 2008. Envisioning the future of water in Europe - the SCENES project. E-Water.

Kok, K., van Delden, H., 2007. Linking Narrative Storylines and Quantitative Models To Combat Desertification in the Guadalentín, Spain. Environment and planning B. 
Lake, P.S., Bond, N.R., 2007. Australian futures: Freshwater ecosystems and human water usage. Futures 39, 288-305.

Lienert, J., Monstadt, J., Truffer, B., 2006. Future Scenarios for a Sustainable Water Sector: A Case Study from Switzerland. Environmental Science \& Technology 40, 436-442.

Maton, L., Leenhardt, D., Goulard, M., Bergez, J.E., 2005. Assessing the irrigation strategies over a wide geographical area from structural data about farming systems. Agricultural Systems 86, 293-311.

Millett, S.M., 1988. How scenarios trigger strategic thinking. Long Range Planning 21, 61-68.

Montginoul, M., Rinaudo, J., 2010. Quels instruments pour gérer les prélèvements en eau souterraine? Le cas du Roussillon. Economie Rurale 310, 40-56.

Nakicenovic, N., Swart, R., 2000. Emissions Scenarios. A Special Report of Working Group II of the Intergovernmental Panel on Climate Change. IPCC, p. 570.

Patel, M., Kok, K., Rothman, D.S., 2007. Participatory scenario construction in land use analysis: An insight into the experiences created by stakeholder involvement in the Northern Mediterranean. Land Use Policy 24, 546-561.

Peterson, G.D., Cumming, G.S., Carpenter, S.R., 2003. Scenario Planning: a Tool for Conservation in an Uncertain World. Conservation Biology 17, 358-366.

Phelps, R., Chan, C., Kapsalis, S.C., 2001. Does scenario planning affect performance? Two exploratory studies. Journal of Business Research 51, 223-232.

Poussin, J.C., Imache, A., Beji, R., Le Grusse, P., Benmihoub, A., 2008. Exploring regional irrigation water demand using typologies of farms and production units: An example from Tunisia. Agricultural Water Management 95, 973-983.

Poux, X.c., 2006. Agriculture, environnement et territoires: quatre scenarios à l'horizon 2025. La Documentation Française, Paris.

Reed, M.S., Arblaster, K., Bullock, C., Burton, R.J.F., Davies, A.L., Holden, J., Hubacek, K., May, R., Mitchley, J., Morris, J., Nainggolan, D., Potter, C., Quinn, C.H., Swales, V., Thorp, S., 2009. Using scenarios to explore UK upland futures. Futures 41, 619-630.

Rinaudo, J.-D., Montginoul, M., Varanda, M., Bento, S., 2012. Envisioning innovative groundwater regulation policies through scenario workshops in France and Portugal. Irrigation and Drainage.

Rotmans, J., van Asselt, M., Anastasi, C., Greeuw, S., Mellors, J., Peters, S., Rothman, D., Rijkens, N., 2000. Visions for a sustainable Europe. Futures 32, 809-831.

Shakley, S., Deanwood, R., 2003. Constructing social futures for climate-change impacts and response studies: building qualitative and quantitative scenarios with the participation of stakeholders. Climate Research 24, 71-90.

Street, P., 1997. Scenario workshops: A participatory approach to sustainable urban living? Futures 29, 139-158.

van der Helm, R., 2003. Challenging futures studies to enhance EU's participatory river basin management. Physics and Chemistry of the Earth, Parts A/B/C 28, 563-570.

van Notten, P.W.F., Rotmans, J., van Asselt, M.B.A., Rothman, D.S., 2003. An updated scenario typology. Futures 35, 423-443.

Varela-Ortega, C., M. Sumpsi, J., Garrido, A., Blanco, M., Iglesias, E., 1998. Water pricing policies, public decision making and farmers' response: implications for water policy. Agricultural Economics 19, 193-202.

Weatherhead, E.K., Knox, J.W., 2000. Predicting and mapping the future demand for irrigation water in England and Wales. Agricultural Water Management 43, 203-218. 
Paper published in Agricultural Water Management, 2013, vol. 130, p. 103-112 (author's version)

Westcott, R., 2004. A scenario approach to demand forecasting. Water Science \& technology 4, 45-55. 